\title{
Evaluation of Latent Membrane Protein 1 as a novel vaccine adjuvant
}

\author{
JM Termini", S Gupta, GW Stone \\ From AIDS Vaccine 2012 \\ Boston, MA, USA. 9-12 September 2012
}

\section{Background}

The EBV protein Latent Membrane Protein-1 (LMP1) is known to constitutively activate B cells. The LMP1 signaling pathway mimics that of CD40, a molecule involved in dendritic cell activation and maturation. Therefore we decided to evaluate the use of LMP1 as a vaccine adjuvant for both dendritic cell therapeutic vaccines and DNA-based vaccines for HIV.

\section{Methods}

To determine activity, LMP1 was analyzed using a luciferase report assay for NF-kB and IFN- $\beta$. To establish if LMP1 could activate human monocyte-derived dendritic cells (DC), LMP1 transfected DC were analyzed for activation/maturation markers and cytokines. DC migration was determined using a transwell-migration assay. LMP1 was also evaluated in a DNA vaccination/flu challenge mouse model. To determine the benefits of incorporating LMP1 into a DC therapeutic vaccine, LMP1 was tested in a tumor DC therapy mouse model.

\section{Results}

LMP1 activated high levels of NF-kB and IFN- $\beta$ when evaluated using a luciferase reported assay. On primary DC, LMP1 induced DC activation, maturation, and proinflammatory cytokines. LMP1 induced 2-fold higher migration rates compared to the mature-DC control. As a DNA vaccine for flu, the addition of LMP1 provided superior TNF- $\alpha$ and IFN- $\gamma$ responses. LMP1 vaccinated animals cleared virus more quickly and in the high-dose lethal flu challenge, LMP1 afforded more protection. Finally, LMP1 enhanced a DC therapeutic vaccine in a tumor model. Tumor progression was slowed compared to antigen-loaded DC alone and positive control mimicmatured DC.

University of Miami, Miami, FL, USA

(C) 2012 Termini et al; licensee BioMed Central Ltd. This is an Open Access article distributed under the terms of the Creative Commons Attribution License (http://creativecommons.org/licenses/by/2.0), which permits unrestricted use, distribution, and reproduction in any medium, provided the original work is properly cited.

\section{Conclusion}

These data suggest that LMP1 is an effective vaccine adjuvant. LMP1 can enhance the activation, maturation, and functional activity of DC. LMP1 can inducing a strong CD8+ $\mathrm{T}$ cell response in several mouse models, increased antigen-specific CD8+ T cells, improved survival to lethal flu high-dose challenge, and slowed tumor progression. These results suggest that LMP1 is a promising adjuvant for prophylactic vaccines for HIV.

Published: 13 September 2012

doi:10.1186/1742-4690-9-S2-P11

Cite this article as: Termini et al:: Evaluation of Latent Membrane

Protein 1 as a novel vaccine adjuvant. Retrovirology 2012 9(Suppl 2):P11. most notably the flu viral challenge model. LMP1
Submit your next manuscript to BioMed Central and take full advantage of:

- Convenient online submission

- Thorough peer review

- No space constraints or color figure charges

- Immediate publication on acceptance

- Inclusion in PubMed, CAS, Scopus and Google Scholar

- Research which is freely available for redistribution 